\title{
Market Rent Determinants of Residential Apartments in Addis Ababa, Ethiopia
}

Masresha Belete 1, and Mesfin Yilma 2

1 Woldia University, Ethiopia.

2 The Ethiopian Institute of Architecture, Building Construction and City Development, Addis Ababa University, Ethiopia.

To cite this article: Belete, M. \& Yilma, M. (2020). Market Rent Determinants of Residential Apartments in Addis Ababa, Ethiopia. Journal of African Real Estate Research, 5(1), pp.7797. DOI: $10.15641 /$ jarer.v5i1.848.

\begin{abstract}
Rapid urbanisation and population growth increase the demand for housing. Given its importance to human wellbeing, the right to housing is recognised in international, regional and domestic legislation. The rental housing sector is the major form of housing tenure in Ethiopia. Given financial constraints, Ethiopian tenants tend to rent instead of buying property. However, there are no well-developed procedures that guide how rental value is determined in Ethiopia. As such, the purpose of this study is to identify monthly rent determinant variables of residential apartments in Ethiopia. Substantial empirical results from different countries indicate that rental value is a result of the combined contribution of the integrated components: property, amenities, and externalities. For this study, a multiple regression model was used for 164 samples taken from three purposefully selected case study areas in Addis Ababa (CMC, Jemo and Kazanchis). The regression results indicate that nine significant variables were determinant variables of monthly rent at a $95 \%$ confidence interval. This study may contribute decisive information for Ethiopian property managers, real estate developers, income tax assessors, real property owners, lending institutions and other interested real estate professionals. It allows these stakeholders to more accurately estimate the monthly rental value and market value of properties for their business evaluation.
\end{abstract}

Keywords: Determinant Variables; Market Rent; Residential Apartments; Addis Ababa; Ethiopia 


\section{Introduction}

Real estate is a heterogeneous product meaning that age, building design, and especially location differences give each property distinctive characteristics. The term real estate refers to land and the immobile or permanent fixtures attached to the land. Its location is unique for each property. The immobile nature of the property yields the heterogeneous aspect of the real estate space and the asset market (Ling \& Archer, 2018). The unique nature of real property and the asymmetry of market information complicate the real estate valuation process, and clients often need professional valuers (Wyatt, 2013). Developing a reliable and accurate valuation system helps to create stability and efficiency in property markets through increased knowledge and understanding. In particular, rental valuation is important as renting is becoming an increasingly popular form of tenure due to the rising, and often inaccessible, cost of buying residential property (Belachew, 2013).

Wickramaarachchi describes the rental housing market as imperfect and inefficient. This is because housing products are long-lasting, fixed on a given site, heterogeneous, and controlled by extensive governmental regulation (Wickramaarachchi, 2017). Furthermore, reviews of substantial empirical studies in different countries indicate that rental value is a result of the combined contribution of integrated components: property, amenities, and externalities. Understanding these integrated components of residential rental values is important for functioning property markets as well as for government institutions when deciding which services would provide the optimal value to businesses and society. Furthermore, they have received very little attention in the context of Ethiopia (Belachew, 2013).

Like the rest of Africa, Ethiopia is currently urbanising at a rapid rate. Addis Ababa, the nation's capital, is home to approximately 3.5 million people (Tolon, 2008). Since 1991, Addis Ababa has been characterised by rapid economic and population growth (Keller \& Mukudi-Omwami, 2017). This creates pressures on the supply and demand for housing which governments alone cannot wholly respond to. In order for market-oriented strategies to meet this growing need for housing; and for the supply of housing to be efficient, effective and just, it is important to understand the dynamic components of urban property markets in Ethiopia. Given that between 70$80 \%$ of Addis Ababa's population is living below the poverty line (Tolon, 2008); housing purchase is not a realistic option for the majority of the city's urban population. Thus, central to delivering an effective and efficient rental real estate market that can supply the housing needs of Addis Ababa is developing an understanding of the components/determinants that support rental values. Presently, this is an area that has received very little research in Ethiopia. To this end, the study aims to identify monthly rent determinant variables in Addis Ababa. The study developed a simple rent estimation model for residential apartments in Addis Ababa. This was achieved by including a number of variables and using regression analysis in order to examine the role of independent variables on the dependent variable (monthly rent) in Ethiopia. 
In terms of contribution, this paper provides real estate developers in Addis Ababa with rent determinants that can help align the supply and demand of housing. It is also likely to help developers optimise their developments as they have a better understanding of a property's value. Additionally, tenants will also benefit from having a clear understanding of rental values. Local government in Addis Ababa could also benefit from a tax collection perspective. Currently, there is no rational and well-developed valuation method to estimate value for tax purposes. Further, governments will benefit by having better tools to decide how to provide urban services in an optimal manner. Finally, other organisations like financial institutions and insurance companies may use this study as the basis in the estimation of monthly incomes for residential apartments in Addis Ababa. When the real estate owners apply to financial institutions for loans for property, financial institutions can easily estimate the amount of debt to issue borrowers using this model.

\section{Theoretical and Empirical Reviews}

\subsection{The Concept, Definition and Rent of Real Property}

The term property refers to things owned by someone. In English law, a property may be a personal property or real property. Personal properties are those that could be moved or detached easily from place to place without detraction of its physical feature whereas, real property refers to land, permanent improvements, and buildings which are commonly termed as real estate (Blackledge, 2009). Some scholars detach the meaning of real property and real estate. According to those scholars, real property refers to the right related to real estate, and real estate refers to the physical, tangible thing (Ling $\&$ Archer, 2018). The right over land may extend beneath and above the surface of the earth, and so real property includes the right to use the land accordingly. The coverage of the right may vary depending on the country's law of real property. For instance, minerals below the surface of the land may be owned by the owner of the land and are real properties in some countries (Hinkel, 2008). However, in Ethiopia, every natural resource belongs to the state and the land possessor, therefore, the owner has no right to use the natural resources (FDRE Constitution, 1995).

The real property market is characterised by heterogeneous products, immovable products, localised markets, segmented markets and high transaction costs (Ling \& Archer, 2018). Housing real property is a multidimensional product differentiated into a bundle of attributes with varying quality, quantity, and hence, value (Wickramaarachchi, 2017). These and other features of the real property market make the market inefficient and complicate the determination of the rental value of the real property. Consequently, information about rental values is blurred, and it is often difficult to ascertain what an appropriate amount is for the use of a landlord's land. It is difficult to ascertain a true value that should be paid for the use of land. Accordingly, landlords tend to set a higher asking price- and the tenant sets a lower asking price- before settling on an agreed amount.

Foremost, rental values may also be needed for different reasons other than the aforementioned purpose. Estimating rental value may, for instance, may 
be needed to grant a new lease; assess the market rent of a letting unit as part of an investment valuation or lease renewal, either by agreement on by thirdparty determination; rent review under an existing lease; and assessment of investment worth (Sayce et al., 2006). In order for rental markets to work effectively and efficiently, understanding the value of a property, and the value of its use through rent is crucial. Thus, having a guiding framework that helps tenants and landlords realise a fair rental price is an important element of a functioning rental housing market.

\subsection{Market Rent Determinant Variables of Residential Properties}

H Rent for real estate may be administered by market rent or contractual rent. Contractual rents are determined by the contract of the parties and obliged for prescribed periods and conditions in the contract. As a result, the contractual rents agreed in the past may not reflect the current market rent determined by market interactions of supply and demand. The contractual rents may be less or more than the market rent for different reasons. First, market rent may have been increased or decreased in the current market environment. Second, the relationship or agreement with the lessor and the lessee could be a factor allowing for the market rent to be higher or lower than the contractual rent. Third, the lessee may have committed to carrying out improvements to the premises. Thus, the difference between market rent and contractual rent may be affected by one or more of the aforementioned reasons (Shapiro, Mackmin \& Sams, 2013).

The second extensively used type of rent is market rent. Market rent could be defined in different ways. Archer and Ling (2018: 195) define market rent as "the rental income the property would most probably command if placed for lease on the open market as of the effective date of the appraisal". This definition suggests that some factors that affect contractual rent may not affect market rent. However, the most comprehensive definition is offered by Wyatt (2013: 58): "market rent is the estimated amount for which a property, or space within a property, should lease on the date of valuation between a willing lessor and a willing lessee on appropriate lease terms, in an armslength transaction, after proper marketing wherein the parties had each acted knowledgeably, prudently and without compulsion".

Sirmans and Benjamin (1991), working with a similar definition, suggest that market rent is determined by a bundle of amenities and facilities, propertyspecific factors and locational factors. Additionally, the rental value is affected by the duration of contractual agreements, the payment mode (in advance or at the end of the period), premiums, freedoms and other variables like sharing of maintenance, insurance, and utility costs. According to Scarrett (2008), the most common physical factors increasing rental value are location, topology, accessibility, geology and other aspects such as exposure to sun, wind and flooding. Furthermore, rental values are affected by other, less material, variables. These could include negotiable elements in the contractual agreement, variations in terms of total length, rent reviews and payment frequency (Baum, Mackmin \& Nunnington, 2011). Furthermore, the length of the lease; presence and wording of rent review clauses; provisions 
regarding repair, alterations, and improvements; provisions for alienation and parting with possession; user clauses; service charge provisions (in the case of a multi-let property); and many onerous provisions such as 'keep open' clauses, play a significant role in the determination of the rental values of residential properties (Sayce et al., 2006).

There have been a number of studies that have explored rent determinants across the world. For instance, Gitahi (2002), studying the Kenyan residential real estate market, identifies some rent determining variables and indicates that the rent for residential property is highly dependent on the number of bedrooms and the size (area in $\mathrm{m} 2$ ) of the main house. These variables are established as significant variables from Gitahi's regression results of rent, he also identifies the title, number of reception rooms, location and number of bathrooms as the independent variables (Gitahi, 2001). Da Cunha Pereira (2017) studied the relationship between Portugual's rental market and housing market. He revealed that the rent and the price of real estate has a positive relationship. The study indicates that an increase in house price will result in an increase in the demand for renting, and thus increasing rent prices. This suggests that the increment of the house price is indirectly a rent determining factor in the Portuguese residential real estate market. The implications state that as the demand for real estate increases, the price of real estate increases. Consequently, housing prices and rentals are directly related. The variables that increase the price of real estate indirectly affects monthly rentals. According to Da Cunha Pereira (2017), the increment in real estate price has an indirect impact on the increment of the rental value.

A study conducted in Ethiopia indicates that there are important relationships between house prices and interest rates as well as GDP and the level of money supply. This study indicates that interest rates have the most significant effect on house prices followed by GDP and the level of money supply (Karoki, 2013). Another study in Sri Lanka indicates that the distance to a university and the floor area per person are key variables in rental values. Furthermore, freely available water, freely available electricity, attached bathroom, and neighborhood characteristics (less congestion and privacy) are highly significant to rental values as second-order factors. Finally, the study suggests that the distance to bus routes, distance to a junction, tiled floors, and a roof with a ceiling were third-order factors in rental values (Wickramaarachchi, 2007). Similarly, a study conducted in Ghana classifies the main factors of rent determination as: location, availability of facilities (toilet and bathroom), availability of amenities (water and electricity) and proximity to the workplace. The result of the study indicates that the impact of the locational characteristics of residential rental prices is statistically significant. The impact of apartment characteristics such as the number of bedrooms, the availability of amenities and availability of facilities are also statistically significant. The sharing of apartment facilities also has a noteworthy impact on residential rental prices. The proximity of an apartment to the place of work is the top priority of most households in considering renting (Amenyah \& Fletcher, 2013). 
Ajilowo and Olujimi (2010), studying Akure in Nigeria, suggest that relationships exist among infrastructural facilities (electricity, water, access roads, toilets, kitchens, drainage channels, wall-fences, waste disposal facilities, day-watch security services, and night watch-security services) in residential properties. These facilities and relationships are key in the determination of the rental value of properties in Akure. Ajilowo and Olujimi use multiple regression models to determine the interrelationships between each of the isolated infrastructures mentioned above. These act as their independent variables while rental values of the residential properties are their dependent variable (Ajilowo \& Olujimi, 2010). Most of the determinant variables for rental values are the same across the world. Other less material variables like negotiable elements in the contractual agreement, variations in terms of total length, rent reviews and payment frequency are significant in developed countries while their high significance is not observed in Africa. Housing rent determinants are diverse and are dependent on many contextual factors, as outlined above. The literature highlights some key factors when looking to model rental price determinants. These studies have been given emphasis due to their locality but also their comparative status. However, given the attention this subject has received internationally, the table below acts to synthesise various studies into a key determinant and thus inform the study. It is broad but key to the overall study.

\section{Table 1: Summary of Reviewed Determinant Variables for Residential Rent Value}

\begin{tabular}{|c|c|c|}
\hline Review & Author & Name of Rent Determinant Variables \\
\hline \multirow{5}{*}{$\begin{array}{l}\text { Theoretical } \\
\text { Review }\end{array}$} & $\begin{array}{l}\text { (Brueggeman \& Fisher, } \\
\text { 2002) }\end{array}$ & $\begin{array}{l}\text { - location, age, quality and condition of premises, access to amenities, } \\
\text { parking, better views, swimming pool, and higher floors with elevators. }\end{array}$ \\
\hline & $\begin{array}{l}\text { Baum, Mackmin \& } \\
\text { Nunnington, 2011) }\end{array}$ & $\begin{array}{l}\text { - length of terms, rent reviews, payment frequency, liability for repair, } \\
\text { insurance, management, and restrictions on use and opening hours. }\end{array}$ \\
\hline & (Sayce et. al., 2006) & $\begin{array}{l}\text { - service charge provisions, alienation (sublet), provisions regarding } \\
\text { repair, alterations, and improvements. }\end{array}$ \\
\hline & (Scarrett, 2008) & $\begin{array}{l}\text { - location, topology, accessibility, geology, construction, age, condition, } \\
\text { layout, and specification affect the value. }\end{array}$ \\
\hline & (Wyatt, 2013) & $\begin{array}{l}\text { - size, age, condition, external appearance, inflation, household } \\
\text { disposable income, consumer spending and retail sales, employment, } \\
\text { construction activity, net household formation, and production costs }\end{array}$ \\
\hline \multirow{4}{*}{$\begin{array}{l}\text { Empirical } \\
\text { Review }\end{array}$} & (Ajilowo \& Olujimi, 2010) & $\begin{array}{l}\text { - electricity, water, access road, toilet, kitchen, drainage channel, } \\
\text { wall/fence, burglary protection, waste disposal facility, day watch- } \\
\text { security services, and night watch-security services. }\end{array}$ \\
\hline & $\begin{array}{l}\text { (Amenyah \& Fletcher, } \\
\text { 2013) }\end{array}$ & $\begin{array}{l}\text { - water and electricity supply, availability of facilities (toilet and } \\
\text { bathroom). }\end{array}$ \\
\hline & (Dabara et al., 2017) & $\begin{array}{l}\text { - unemployment/retrenchment, improper tenant selection, neglect in } \\
\text { repair/maintenance, and unilateral rent affect the rent. }\end{array}$ \\
\hline & $\begin{array}{l}\text { (Attakora-amaniampong, } \\
\text { Owusu-Sekyere, \& } \\
\text { Aboagye, 2016) }\end{array}$ & - Risk of flooding affects rentals and value. \\
\hline
\end{tabular}




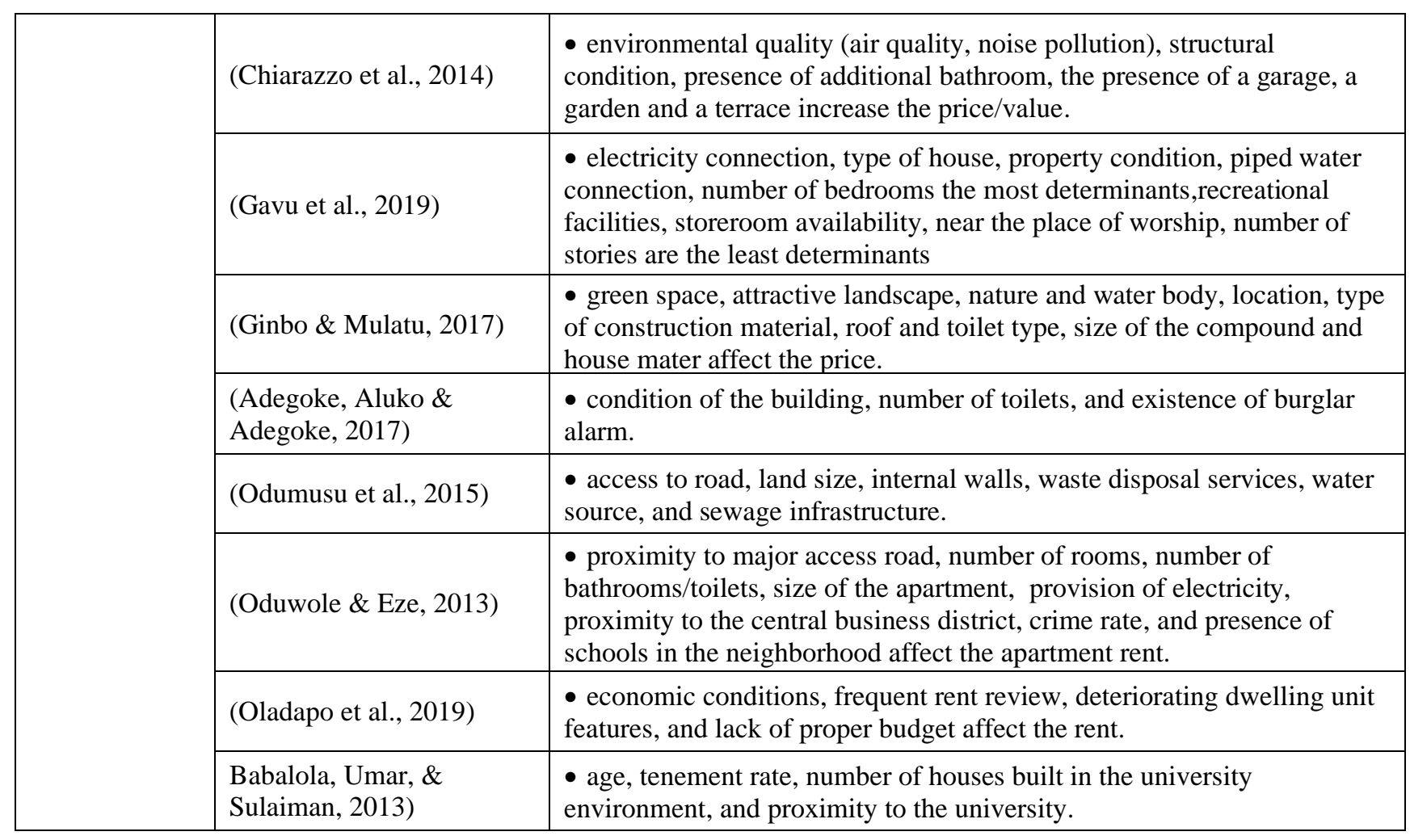

\subsection{The Residential Rental Housing Market in Addis Ababa}

According to Ajilowo \& Olujimi (2010), housing represents the most basic of human needs, and it has a profound impact on the health, welfare, and productivity of individuals. Rapid urbanisation and population growth in developing countries, like in cities such as Addis Ababa, has caused a shortage of housing. The existing housing stock in Addis Ababa is generally of a poor quality, with many settlements being congested and unplanned. According to estimates by the Ministry of Works and Urban Development, the housing deficit in Addis Ababa was about 300,000 units in 2015. Another indicator of the demand for housing was the Government Condominium Lottery of April 2010 which received a total of 485,000 individual entries (The Centre for Affordable Housing Finance in Africa, 2017). The most recent and accurate figures relating to the housing demad in Addis Ababa was an outcome of a joint study with the Central Statistical Authority and the University of Roma, who estimated the demand for housing in Addis Ababa to be 578,547 units in 2010 for a population of 3,327,498 (Abelti \& Brazzoduro, 2001). What is even more worrying about increasing deficit is that the problem has worsened between the two censuses surveys of 1994 and 2007. This highlights the critical need to supply housing into the real estate market of Addis Ababa.

The real estate sector has been one of the fastest-growing segments of the Ethiopian economy. The real estate sector grew in real terms by an annual average of $14.1 \%$ over a five-year period ending in 2009 (Access Capital, 2010). Although the housing stock supplied by the private real estate sector was still minimal, the sector has significantly grown post-1991 with a focus on high-income households in Addis Ababa. Licensed real estate developers 
continuously construct real estate space for tenants and buyers, but a significant challenge is how the rent and sale price for each property is determined. According to Belete (2019), as is the case in most global contexts, the rental value in Ethiopia is affected by different variables. Significant variables affecting rental value include: household income, the structure of the housing unit, household structure, and city/town size (Belete, 2019). The study, analysing the choice of residential property buyers in Addis Ababa, indicates that buyers are willing to pay more for attractive landscapes and accessibility of green space. In addition to those variables, the number of total rooms, number of bedrooms, size of the house, location, types of construction materials, roof and toilet types, and the size of the house determine the demand for rental housing and hence the value of the residential property (Ginbo \& Mulatu, 2017). Another study looking at the rental value in the Ethiopian city of Hawasa, notes that this area has differing determinant variables, for example: the number of rooms in the housing unit, the total area occupied by the house, public transport availability, and healthcare availability and housing typology (Hirboro, Batu \& Aseffa, 2017). Despite this, rent value determinant variables have not been studied in great detail in Ethiopia. By defining clear market rent determinants for housing in Ethiopian cities like Addis Ababa, this study will support market-oriented strategies to supply urban areas with appropriate housing for their growing populations. The following section provides an outline of the methodological approach adopted to help identify market rent determinants in Addis Ababa.

\section{Methodology and Data Collection}

The ultimate aim of this study is to examine the statistically significant rent determinant variables of residential apartments in Addis Ababa. In doing so, the researchers assessed the study areas and focused on specific properties. Structured questionnaires were prepared in line with the literature. Data relating to rent and the independent variables were collected, and later, the data was analysed to examine the determinant variables of the rental value of the residential apartments in Addis Ababa. This section further outlines the rationale relating to the site-sampling, data collection and analysis.

\subsection{Site Location and Description}

Ethiopia has a rapidly increasing urban population, especially in the capital city, Addis Ababa. Addis Ababa occupies a total area of approximately 52,000ha. The city has ten sub-cities and the total population according to the 2007 census was $2,739,551$. This population has grown to 3,434,000 within ten years (CSA, 2017). As a result, there is a significant and growing housing deficit. Thus, the state needs to provide adequate real estate assets and real estate space policy in the long-run to respond to this growing deficit.

The selected study areas are Jemo, Kazanchis and CMC . The total area of the study sites is about 450ha (Jemo, 150ha; CMC, 220ha; and Kazanchis, 80ha). The total number of tenanted residents living within all the study area is approximately 2,500 households, of which 1,602 tenants live in CMC, 152 tenants live in Kazanchis, and the remaining 746 tenants live in Jemo. About $42.7 \%$ of the tenants in the study area are couples, followed by more than two 
family members $(33.5 \%)$. The rest of the tenants are single $(22.1 \%)$, and temporarily coupled with others $(1.7 \%)$. The majority of the tenants $(52.2 \%)$ occupy middle-income households, and the rest of the tenants are high and low-income tenants, representing $38.4 \%$ and $9.4 \%$ respectively. The study areas were purposefully selected for a number of reasons. Firstly, the sites are newly emerging, and there is a concentration of newly constructed apartments in these areas and would give a more reliable depiction of the value of apartments coming into the residential real estate market. Secondly, the areas were selected from across Addis Ababa, given their locational effect on residential rental values. There are three site levels set by the government in Addis Ababa. CMC, Kazanchis and Jemo are in the first, second and third level sites respectively and the sites have been chosen to include these differences. Thirdly, there are a large number of completed residential buildings in these areas meaning there is an existing real estate market where apartments are actively being rented and sold.

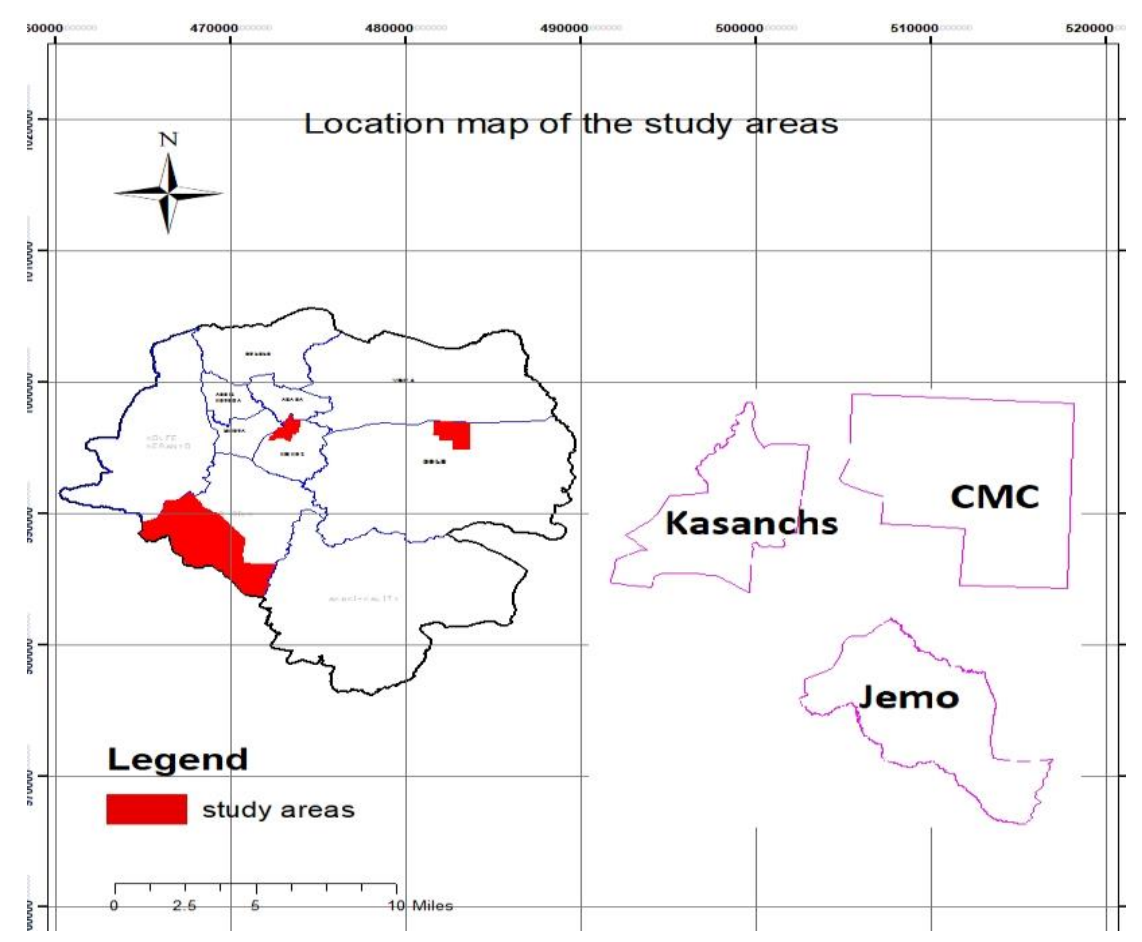

Figure 1: Location of the Case Study Areas in Addis Ababa Source: Compiled the authors using AutoCAD

\subsection{Dependent and Independent Variables}

There are many variables that affect monthly rental values for residential properties. As a starting point, this paper has chosen 15 variables to study closely which was guided by the literature review. These independent variables were also selected based on the nature and type of apartments in the study areas. For instance, the type of construction material for wall work has a significant effect on monthly rentals as highlighted by other studies (see Table 1). But the type of construction material is the same (block walling) for all apartments in the case study areas and in this case, it is not considered. Insteadm and external wall finish is considered. Similarly, other variables are excluded based on the type and nature of the property. This will be outlined 
later in the paper. The list of independent variables that is provided in Table 2 and is based on the review of literature pertaining to determinant variables for residential properties' rental value.

Table 2: List of Independent Variables

\begin{tabular}{|l|l|}
\hline Number & Independent Variable \\
\hline 1 & External Wall Finish (EWF) \\
\hline 2 & Internal Area of Housing Unit (A) \\
\hline 3 & Number of Bathrooms (BA) \\
\hline 4 & Number of Bedrooms (NB) \\
\hline 5 & Floor Level of the Housing Unit (FL) \\
\hline 6 & Access to a Balcony (AB) \\
\hline 7 & Access to Road Type (RT) \\
\hline 8 & Water Supply (WS) \\
\hline 9 & Good Environmental View (GV) \\
\hline 10 & Access to a Lift (AL) \\
\hline 11 & Security (SC) \\
\hline 12 & Access to Parking Area (AP) \\
\hline 13 & Site Location (SL) \\
\hline 14 & Access to Swimming Pool (SP) \\
\hline 15 & Environmental Pollution (PO) \\
\hline
\end{tabular}

When there are two or more independent variables, the relationship analysis is known as multiple correlations, and the equation describing such a relationship is a multiple regression analysis (Kothari, 2004). The 15 independent variables and the correlation between the dependent and independent variables are explained by a multiple regression model. Cramer (2003: 59) defines multiple regression as "a statistical technique for determining what proportion of the variance of a continuous, preferably normally distributed, variable is associated with, or explained by, two or more other variables, taking into account the associations between those other variables". Henceforth, multiple regressions are used in this study. The preliminary model is developed as:

$$
\begin{gathered}
\text { Monthly Rent }=\mathrm{F}(\mathrm{C}+\mathrm{a} 1 \mathrm{~A}+\mathrm{a} 2 \mathrm{AB}+\mathrm{a} 3 \mathrm{SC}+\mathrm{a} 4 \mathrm{AP}+\mathrm{a} 5 \mathrm{NB}+\mathrm{a} 6 \mathrm{RT}+ \\
\mathrm{a} 7 \mathrm{AL}+\mathrm{a} 8 \mathrm{EWF}+\mathrm{a} 9 \mathrm{SL}+\mathrm{a} 10 \mathrm{BA}+\mathrm{a} 11 \mathrm{GV}+\mathrm{a} 12 \mathrm{WS}+\mathrm{a} 13 \mathrm{PO}+\mathrm{a} 14 \mathrm{FL}+ \\
\mathrm{a} 15 \mathrm{SP}+\mu \mathrm{i})
\end{gathered}
$$

Where:

$\mathrm{C}=$ Constant

a1-a15= Coefficients

$\mu \mathrm{i}=$ Error term

\subsection{Sampling Techniques and Population}

The population of the study includes the total number of private residential apartments in Addis Ababa. From the CMC site, there were three types of private apartments identified. The first were high rise apartments constructed by Tsehay Real Estate Plc. These housing units have access to a lift and have relatively better views and security. The second category were housing units constructed by Sunshine Real Estate Plc. These apartments are not high rise and hence have no access to a lift. The last type of housing units were apartments that were constructed by cooperatives and government-organised 
individuals. These types of apartments have a total of 16 housing units with five floor levels (ground plus four levels). The second site is Kazanchis. Ayat Real Estate constructed the apartments in this area. From this site, there are medium-rise buildings (ground level plus eight stories), and of these three apartments were included. The last site, Jemo, has low rise apartments (ground level plus four stories) constructed by Nasew Real Estate Plc.

The study areas were selected purposefully, and a detail case study of these areas was conducted. The study selected 164 private rented residential housing units (see breakdown of selected units in Table 3). Since the housing units were different from each other; data was collected carefully to encompass the identified variables. Hence, households were selected to encompass the range of variables in Table 2. For example, varying floor levels, variations in the number of bedroom and bathroom, views, access to parking and type of external wall finish that has relevant variations for which purposefully samples were taken.

Table 3: Breakdown of Selected Housing Units for the Study

\begin{tabular}{|c|c|}
\hline Study Area & Number of Units Studied \\
\hline CMC & $106(53$ on each level $)$ \\
\hline Jemo & 32 \\
\hline Kazanchis & 26 \\
\hline
\end{tabular}

\section{General Description of the Data}

\subsection{Composition of the Independent Variables}

The housing units of residential apartments in the study area have different attributes. Based on these variable determinants, there are generally 15 hypothesised independent variables selected as determinants (See Section 3.2). However, two of the independent variables highlighted in the literature (internal area of the housing unit and floor level of the housing unit) were not included in the regression analysis as they contain too many divergent types. Hence, they have been explained are better explained by a histogram, given their unit measurements. This is discussed below. The 13 independent variables associated with the housing units in the study areas are summarised in Table 4 below.

Table 4: Compositions of Independent Variables for Residential Apartments

\begin{tabular}{|l|l|l|l|l|l|}
\hline \multirow{2}{*}{ Variable Name } & $\begin{array}{c}\text { Type of } \\
\text { Variable }\end{array}$ & Description & Frequency & Percentage & Subtota1 \\
\hline \multirow{2}{*}{$1 . \quad$ Bedrooms } & \multirow{2}{*}{ Interval } & Studio & 7 & $4.3 \%$ & \multirow{2}{*}{$100 \%$} \\
\cline { 3 - 5 } & & One bedroom & 20 & $12.2 \%$ & \\
\cline { 3 - 5 } & & Two bedroom & 62 & $37.8 \%$ & \\
\hline
\end{tabular}


Journal of African Real Estate Research Volume 5(1) 2020

\begin{tabular}{|c|c|c|c|c|c|}
\hline & & Three bedroom & 75 & $45.7 \%$ & \\
\hline \multirow{2}{*}{ 2. Security } & \multirow{2}{*}{ Dummy } & Secured & 34 & $20.7 \%$ & \multirow{2}{*}{$100 \%$} \\
\hline & & Not secured & 130 & $79.3 \%$ & \\
\hline \multirow{3}{*}{ 3. Site location } & \multirow{3}{*}{ Categorical } & CMC & 106 & $64.6 \%$ & \multirow{3}{*}{$100 \%$} \\
\hline & & Kazanchis & 32 & $19.5 \%$ & \\
\hline & & Jemo & 26 & $15.9 \%$ & \\
\hline \multirow{2}{*}{$\begin{array}{l}\text { 4. Number of } \\
\text { bathrooms }\end{array}$} & \multirow{2}{*}{ Interval } & One bathroom & 27 & $16.5 \%$ & \multirow{2}{*}{$100 \%$} \\
\hline & & Two bathroom & 137 & $83.5 \%$ & \\
\hline \multirow{2}{*}{$\begin{array}{l}\text { 5. Access to } \\
\text { balcony }\end{array}$} & \multirow{2}{*}{ Dummy } & Access & 144 & $87.8 \%$ & \multirow{2}{*}{$100 \%$} \\
\hline & & No access & 20 & $12.2 \%$ & \\
\hline \multirow{2}{*}{ 6. Parking } & \multirow{2}{*}{ Dummy } & Access & 148 & $90.2 \%$ & \multirow{2}{*}{$100 \%$} \\
\hline & & No access & 16 & $9.8 \%$ & \\
\hline \multirow{2}{*}{ 7. Elevator } & \multirow{2}{*}{ Dummy } & Access & 54 & $32.9 \%$ & \multirow{2}{*}{$100 \%$} \\
\hline & & No access & 110 & $67.1 \%$ & \\
\hline \multirow{3}{*}{ 8. Access to road } & \multirow{3}{*}{ Categorical } & Natual ground & 42 & $25.6 \%$ & \multirow{3}{*}{$100 \%$} \\
\hline & & Gravel & 68 & $41.5 \%$ & \\
\hline & & Asphalt & 54 & $32.9 \%$ & \\
\hline \multirow{2}{*}{ 9. Access to Water } & \multirow{2}{*}{ Dummy } & Sufficient & 94 & $57.3 \%$ & \multirow{2}{*}{$100 \%$} \\
\hline & & Insufficient & 70 & $42.7 \%$ & \\
\hline \multirow{2}{*}{ 10. View } & \multirow{2}{*}{ Dummy } & Good view & 67 & $40.9 \%$ & \multirow{2}{*}{$100 \%$} \\
\hline & & No view & 97 & $59.1 \%$ & \\
\hline \multirow{2}{*}{$\begin{array}{l}\text { 11. External wall } \\
\text { finish }\end{array}$} & \multirow{2}{*}{ Categorical } & Quartz & 142 & $86.6 \%$ & \multirow{2}{*}{$100 \%$} \\
\hline & & Granite paint & 22 & 13.4 & \\
\hline \multirow{2}{*}{$\begin{array}{l}\text { 12. The existence of } \\
\text { pollution }\end{array}$} & \multirow{2}{*}{ Dummy } & Pollution & 16 & $9.8 \%$ & \multirow{2}{*}{$100 \%$} \\
\hline & & No Pollution & 148 & $90.2 \%$ & \\
\hline 13. Swimming pool & Dummy & $\begin{array}{l}\text { All have no } \\
\text { access }\end{array}$ & 164 & $100 \%$ & $100 \%$ \\
\hline
\end{tabular}

\subsection{Area of the Housing Units}

The area of the housing unit was the other variable hypothesised as the determinant variable of the market rent for the residential apartments. The majority of the housing units were within the area of $50 \mathrm{~m} 2$ and $100 \mathrm{~m} 2$. The minimum internal area was $27 \mathrm{~m} 2$ for studios and the maximum area was $171 \mathrm{~m} 2$ for three bedrooms as indicated below. Due to the fact that the majority of the apartments fell within the same category of size $(50-100 \mathrm{~m} 2)$ it was decided to explain this independent variables separately. 


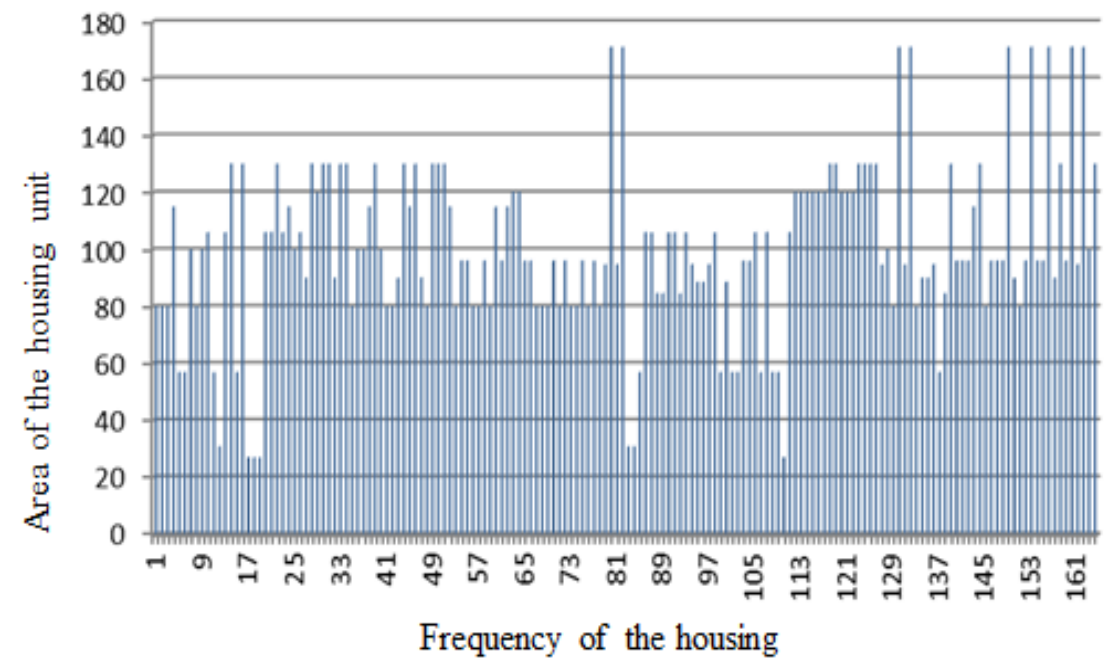

Figure 2: Area of the Housing Unit versus the Number of Housing Unit Source: Field Survey, 2018

\subsection{Floor Level of the Housing Units}

The floor level of the housing unit affects the monthly rental value. There is little demand for floor levels above the first floor for commercial shopping units (Wyatt, 2007).On the contrary, scholars of residential property argue that the price and the rental value for highrise apartments increases as the floor level increases due to the number of extrinsic and intrinsic qualities (Larcombe et al., 2019). The floor level has a positive premium on rent as it increases, but this premium diminishes as the level increases over a certain threshold (Chau, Yau, \& Cheung, 2011; Wong et al., 2011). In the case study areas, the floor level of the housing units ranges from 1 to 12. Based on the availabilities, this composition is indicated below in Figure 4.

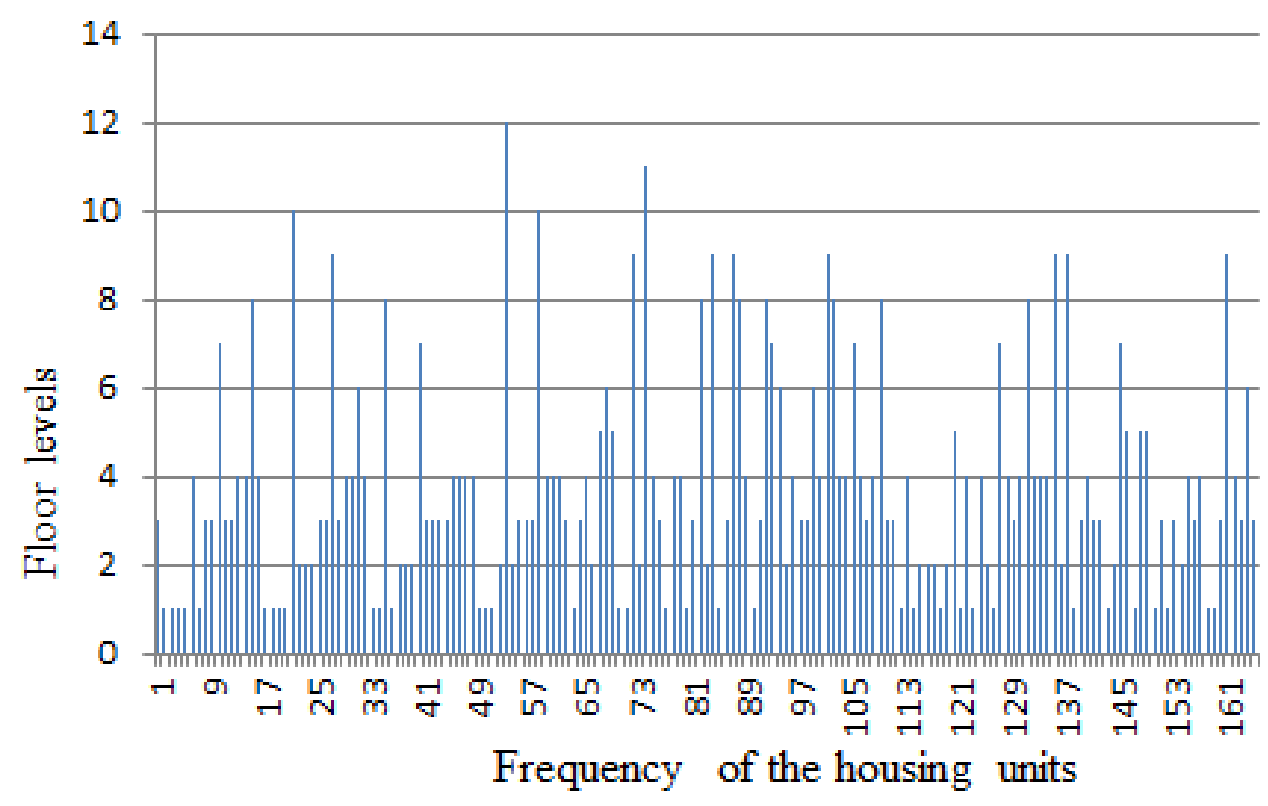

Figure 4: Floor Level Composition of the Housing Units

Source: Field Survey, 2018 


\section{Data Analysis}

According to Pennings, Keman and Kleinnijenhuis (2006), multiple regression analysis should meet the assumption of linear relationships- no multicollinearity, homoscedasticity and no autocorrelation. The study tested all the assumptions of linear regression, and the results of the test indicates as all significant except for the normality test. The result of the normality test (Shapiro Wilk W test) of the data suggests that the data is non-normal. Pennings, Keman and Kleinnijenhuis (2006) argue that non-normal data is generated when study participants fail to respond to specific questions or researchers miss observations. As such, inaccurate data is rejected from the database. Relating this to the current study, some tenants were reluctant to tell the truth about monthly rentals in the structured questionnaires and this created non-normal data distribution. The researchers transformed the data to address this issue. Data transformation is a mechanism of designating specific value to represent missing data using SPSS or SAS statistical tools. Transforming the data, rather than rejecting the incorrect value, helps to reduce the skewness and help to precisely analyse the data (Marczyk, DeMatteo \& Festinger, 2005). Hence the data of this study transformed using SPSS and the normality test for the transformed data was completed. The result of the test is indicated in the Table 5 below.

The Shapiro Wilk W test was first developed by Shapiro and Wilk in 1965 (Shapiro \& Wilk, 1965). According to this test, there are null and alternative hypothesis which are stated as:

Ho: The sample data are normally distributed

Ha: The sample data are significantly different than a normal population

The test recommends rejecting the null hypothesis when the P-value is less than the selected alpha value (in this case 0.05 ) and accept the null hypothesis if it is greater than the alpha value. The result of the Shapiro Wilk W test for the transformed data indicates that the data is now normal. The P-value (0.14951), in Table 5, implies that the null hypothesis is accepted, and the alternative hypothesis is rejected, i.e. the data is now normal.

\section{Table 5: Normality Test for Monthly Rents After the Data Transformation}

\begin{tabular}{|l|c|c|c|c|c|}
\hline Variable & Obs & W & V & Z & Prob>z \\
\hline Rent 1 & 164 & 0.98556 & 1.584 & 1.039 & 0.14951 \\
\hline
\end{tabular}

The next part of this analysis requires a match of independent and dependent variables; this is indicated in Table 6.

Table 6: Model Summary of Multiple Regression Results

\begin{tabular}{|c|c|c|c|c|c|}
\hline Model & $\mathbf{R}$ & $\mathbf{R}$ Square & $\begin{array}{c}\text { Adjusted R } \\
\text { Square }\end{array}$ & $\begin{array}{c}\text { Std. Error of } \\
\text { the Estimate }\end{array}$ & Durbin-Watson \\
\hline 1 & $.952 \mathrm{a}$ & .907 & .898 & .130 & 1.827 \\
\hline
\end{tabular}


Table 6 specifies how much the independent variables predict the dependent variable. The adjusted R Square value (in this study, 0.898) is the percentage of variation explained by the independent variables that affect the dependent variable. This means the independent variables predict the dependent variables at $89.8 \%$ (adjusted $\mathrm{R}$ square). The significance level of the model may also explain this inception and it is also very high ( 0.00 which is less than 5\% alpha value) as indicated below in Table 7.

\section{Table 7: Significance of the Model for the Monthly Rent of Residential Apartments (ANOVA)}

\begin{tabular}{|c|l|c|c|c|c|c|}
\hline \multicolumn{2}{|c|}{ Model } & Sum of Squares & Df & Mean Square & F & Sig. \\
\hline \multirow{3}{*}{1} & Regression & 24.650 & 15 & 1.761 & 103.739 & $.000 \mathrm{~b}$ \\
\cline { 2 - 7 } & Residual & 2.529 & 149. & .017 & & \\
\cline { 2 - 7 } & Total & 27.179 & 164 & & & \\
\hline
\end{tabular}

The linear regression result in Table 8 indicates that the nine constant variables (area of the apartment, access to a balcony, the security of the compound, access to road, access to a parking area, number of bedrooms, access to lift, type of external wall finish and the location of the site) affect the rental value of residential apartments in the case study areas. The remaining five variables (floor level, access to a bathroom, environmental pollution, good environmental view and sufficient access to water) do not statistically affect the rental value of private apartments in the study areas. Furthermore, the data shows that the rent of upper-level apartments decreases when there is no access to a lift. From the demography, the interest of tenants in upper floor level dwellings decreases as the age and family size increases. As indicated in Table 8, the floor level has a P-value of 0.484 , which is greater than $5 \%$ of the alpha value and is therefore insignificant for this study and needs further study. The number of bathrooms is another insignificant variable in the case study areas. The result of this study indicates that tenants are not willing to pay for an additional bathroom. As a result, additional bathrooms beyond one has no effect on the monthly rent, i.e. keeping other things constant, the rental value of housing units with one and two bathrooms is the same. Contrary to Chiarazzo et al. (2014), having a good environmental view and the existence of environmental pollution are also insignificant variables for residential apartments, i.e. tenants are not willing to pay more for these attributes. Finally, the swimming pool variable has no variation in the study areas, and therefore its statistical significance could not be tested.

Table 8: Significance of Independent Variables for Residential Apartments

\begin{tabular}{|c|c|c|c|c|c|c|c|c|}
\hline \multicolumn{9}{|c|}{ Coefficientsa } \\
\hline \multirow{2}{*}{\multicolumn{2}{|c|}{ Model }} & \multicolumn{2}{|c|}{$\begin{array}{c}\text { Unstandardised } \\
\text { Coefficients }\end{array}$} & \multirow{2}{*}{$\begin{array}{c}\begin{array}{c}\text { Standardised } \\
\text { Coefficients }\end{array} \\
\text { Beta }\end{array}$} & \multirow{2}{*}{$\mathbf{t}$} & \multirow{2}{*}{ Sig. } & \multicolumn{2}{|c|}{$\begin{array}{l}\text { 95.0\% Confidence Interval } \\
\text { for B }\end{array}$} \\
\hline & & B & $\begin{array}{l}\text { Std. } \\
\text { Error }\end{array}$ & & & & Lower Bound & Upper Bound \\
\hline 1 & (Constant) & 8.354 & .088 & & 95.144 & $.000_{* *}$ & 8.180 & 8.527 \\
\hline
\end{tabular}




\begin{tabular}{|c|c|c|c|c|c|c|c|}
\hline Floor level & -.004 & .006 & .022 & .702 & .484 & -.007 & .015 \\
\hline Floor area & .002 & .001 & .162 & 2.557 & $.012 *$ & .001 & .004 \\
\hline Access to balcony & .240 & .030 & .039 & 3.326 & $.000 * *$ & -.020 & .101 \\
\hline $\begin{array}{l}\text { security of the } \\
\text { compound }\end{array}$ & .361 & .067 & .384 & 5.400 & $.000 * *$ & .229 & .494 \\
\hline Parking area & .071 & .030 & .083 & 2.347 & $.020 *$ & .011 & .131 \\
\hline Number of bedroom & .282 & .048 & .470 & 5.886 & $.000 * *$ & .188 & .377 \\
\hline Access to road & .135 & .039 & .285 & 3.469 & $.001 *$ & .058 & .212 \\
\hline Access to lift & .196 & .047 & .241 & 4.146 & $.000 * *$ & .103 & .290 \\
\hline External wall finish & .106 & .031 & .133 & 3.474 & $.001 *$ & .046 & .167 \\
\hline $\begin{array}{l}\text { Environmental } \\
\text { pollution }\end{array}$ & -.056 & .047 & -.052 & -1.176 & .242 & -.149 & .038 \\
\hline Bathroom & -.008 & .051 & -.009 & -.151 & .880 & -.108 & .093 \\
\hline Location of the site & -.071 & .026 & -.132 & -2.772 & $.006^{*}$ & -.122 & -.020 \\
\hline $\begin{array}{l}\text { Sufficient access to } \\
\text { water supply }\end{array}$ & .037 & .024 & .042 & 1.523 & .130 & -.011 & .084 \\
\hline $\begin{array}{l}\text { Good environmental } \\
\text { view }\end{array}$ & .027 & .025 & .029 & 1.065 & .289 & -.023 & .077 \\
\hline
\end{tabular}

Based on the regression result of the data in Table 8, the theoretical model indicated under Section 3.2 of the methodology could be re-written by excluding insignificant variables as:

Monthly Rent $=\mathrm{F}(\mathrm{C}+\mathrm{A}+\mathrm{AB}+\mathrm{SC}+\mathrm{AP}+\mathrm{NB}+\mathrm{RT}+\mathrm{AL}+\mathrm{EWF}+\mathrm{SL})$

Where:

C=Constant

Table 9. Updated List of Independent Variables

\begin{tabular}{|l|l|}
\hline Number & Independent Variable \\
\hline 1 & External Wall Finish (EWF) \\
\hline 2 & Internal Area of Housing Unit (A) \\
\hline 3 & Number of Bedrooms (NB) \\
\hline 4 & Access to a Balcony (AB) \\
\hline 5 & Access to Road Type (RT) \\
\hline 6 & Access to a Lift (AL) \\
\hline 7 & Security (SC) \\
\hline 8 & Access to Parking Area (AP) \\
\hline 9 & Site Location (SL) \\
\hline
\end{tabular}

As mentioned earlier, to reduce the skewness of the data, the original data has been is transformed. Therefore, the model with the constant and the coefficients can be re-written as: 


$$
\begin{gathered}
\text { Log (Monthly Rent })=(8.354+0.002 * \mathrm{~A}+0.024 * \mathrm{AB}+ \\
0.361 * \mathrm{SC}+0.071 * \mathrm{AP}+0.282 * \mathrm{NB}+0.135 * \mathrm{RT}+0.196 * \mathrm{AL}+0.106 * \mathrm{EWF}+ \\
(-0.071) \mathrm{SL}
\end{gathered}
$$

This model, therefore, suggests that as the area increases by one unit, the rent increase by $(0.2 \%)$. Furthermore, with access to a balcony, parking area, lift, and security in the compound, the rent increases by $2.4 \%, 28.2 \%, 19.6 \%$, and $7.1 \%$ respectively. Keeping other variables constant, the monthly rent of an apartment with a balcony increases by $2.4 \%$. Similarly, the rent of an apartment unit that has a common parking area in the compound is greater than an apartment that has no access to the parking area by $28.2 \%$. The security of the compound is defined in terms of a fence and guard. The monthly rent of an apartment that has fence and guard exceed those without by $36.1 \%$. For road type, the access to gravel road increases the monthly rent of private residential apartments by $13.5 \%$, whereas natural ground roads decrease rents by $13.5 \%$ from the asphalt road alternative. The monthly rent of apartments with two-bedrooms decreases by $28.2 \%$ from a three-bedroom apartment. Furthermore, the rent of a two-bedroom apartment increases by $28.2 \%$ from a one-bedroom dwelling. Similarly, the monthly rent of a studio decreases by $28.2 \%$ from a single bedroom rental. The monthly rent of the apartments with aluminum plaster external wall finishes increase by $10.6 \%$ compared to quartz external wall types.

The last determinant variable is the location of the site. Location is represented as categorical data, with a total of three categories. The researchers use a weighted effect coding method for this analysis. A weighted effect coding method is a mechanism of representing categorical variables with different weights other than the dummy coding. As the criteria for dummy coding assigns 0 and 1 , the criteria for weighted effect coding requires the sum of the code to equal zero (Nieuwenhuis, Grotenhuis \& Pelzer, 2017). The result of this coding associates the second and third element and hence Kazanchis which is represented as 0 is the reference. Based on this categorical coding of results the average monthly rent of apartments at Jemo site is $7 \%$ lower than the Kazanchis (negative coefficient) whereas Kazanchis site is 7\% lower than the CMC site.

\section{Conclusion}

Urbanisation and population growth create pressures on the supply and demand for housing which governments alone cannot respond to. As a consequence, private real estate developers play a critical role in supplying residential housing units in areas like Addis Ababa that are rapidly urbanising. Given many urban dwellers in Addis Ababa cannot afford to own houses, the rental market is key to easing the ever-growing demand for housing stock. Thus, market-oriented approaches for supplying rental housing to the real estate market needs to be supported. This study aims to contribute to delivering an effective and efficient rental real estate market by identifying the rental determinant variables of residential apartments in Addis Ababa, Ethiopia. 
Market rent of residential apartments is affected by different factors. The determinant variables are property-specific factors and environmental factors such as a bundle of amenities and facilities, property-specific factors and locational factors. The identification of these determinants is important for governmental and non-governmental actors: property managers, real estate developers, income tax assessors, real property owners, lending institutions and other interested real estate professionals. This type of information allows stakeholders to estimate monthly rental values and the market value of property more efficiently. Hence, this study provides a model for estimating monthly rental incomes for a range of actors related to residential apartments in Addis Ababa.

This study purposefully studied 164 apartment housing units across three selected case study areas in Addis Ababa. Based on the literature review, 15 independent variables were identified based on their impact on monthly rent values. These variables were analysed through multiple regression analysis. The regression results indicate that nine variables affect the rental value of residential apartments in the case study areas. These nine determinants were further categorised into first level rent determinants and second-level rent determinants. The first-level factors include the number of bedrooms, access to a balcony, the security of the compound, and access to a lift. These had the most significant impact on the rental value. The second-level factors are access to a road, access to a parking area, area of the apartment, type of external wall finish, and the location of the site. The study found that the floor level and number the of bathrooms in the housing units did not impact the rental price. Additionally, good environmental view, access to a swimming pool, environmental pollution and access to water supply did not impact rent determinant variables in this study, and needs further study for those variables. Understanding these variables will help real estate developers optimally supply the housing market with units that provide the most value to tenants.

\section{References}

Abelti, G., Brazzoduro, M. \& Gebremedhin, B. (2001). Housing conditions and demand for housing in urban Ethiopia: In-depth studies from the 1994 population and housing census in Ethiopia. Addis Ababa: Central Statistic Authority \& National Research Council.

Access Capital. (2010). Ethiopian real estate sector report, Investing in Ethiopia. [Online]. Available at: www.ethioconstruction.net/sites/default/files/Law.

Adegoke, O.J., Aluko, B.T. \& Adegoke, B.F. Determinants of Market Value of Residential Properties in Ibadan. Journal of Economics and Sustainable Development, 8(4), pp.178-188.

Ajilowo, J. \& Olujimi, B. (2010). Analysis of the Relationships of Infrastructural Facilities in the Determination of Rental Values of Residential Properties in Akure, Nigeria. Arts and Social Sciences 
Journal, (ASSJ-10), pp.1-11.

Amenyah, I.D. \& Fletcher, E.A. (2013). Factors Determining Residential Rental Prices. Asian Economic and Financial Review Journal, 3(1), pp.39-50.

Archer, W. \& Ling, D. (2012). Real Estate Principles. A Value Approach. McGraw-Hill Higher Education.

Attakora-amaniampong, E., Owusu-Sekyere, E. \& Aboagye, D. (2016). Urban Floods and Residential Rental Values Nexus in Kumasi, Ghana. Ghana Journal of Development Studies, 13(2), pp.176-194.

Babalola, S.J., Umar, A.I., \& Sulaiman, L.A. (2013). An Economic Analysis of Determinants of House Rents in the University Environment. European Scientific Journal, 9(19), pp.99-111.

Baum, A., Mackmin, D. \& Nunnington, D. (2011). The Income Approach to Property Valuation (Sixth edition). United Kingdom: Elsevier Ltd. Belachew, T.M. (2013). Housing Tenure in Ethiopia, Empirical Study on Private Residential Tenancy in Bahir Dar City. In proceedings of FIG Working Week, May 6-10. Abuja, Nigeria.

Blackledge, M. (2016). Introducing Property Valuation. London: Taylor \& Francis.

Brueggeman,W.B. \& Fisher, J.D. (2002). Real Estate Finance and Investments (11th eds). United States: McGraw-Hill.

Chiarazzo, V., Coppola, P., Ibeas Portilla, Á. \& Ottomanelli, M. (2014). The Effects of Environmental Quality on Residential Choice Location, Procedia - Social and Behavioral Sciences, 162, pp.178-187.

Cramer, D. (2003). Advanced Quantitative Data Analysis. United Kongdom: McGraw-Hill Education.

da Cunha Pereira, S.M. (2017). Exploring the Relationship between Residential Rents and House Prices in the Portuguese Residential Real Estate Market In Portuguese. Masters dissertation, Faculty of Economics, University of Porto.

Dabara, D.I., Anthony, A.I., Olusegun, O.J., Eleojo, A.G. \& Michael, A.O. (2017). Rent Default Factors in Residential Properties in Osogbo Metropolis Osun State, Nigeria. International Journal of Business and Management Studies, 6(1), pp.61-68.

Durbin, J. \& Watson, G.S. (1971). Testing for serial correlation in least square regression. III. Biometrika, 58(1), pp.1-19.

FDRE Constitution. (1995). Constitution of the Federal Democratic Republic of Ethiopia. Proclamation No.1, 1st Year, Addis Ababa - 21 st August, 1995).

Gavu, E.K., Gruehn, D., Schulte, K.W. \& Asante, L.A. (2019). Stakeholders' Perception of Residential Rental Value Determinants. Journal of African Real Estate Research, 4(1), pp.42-70. DOI: 10.15641/jarer.v4i1.704.

Ginbo, T \& Mulatu, D.W. (2017). Residential Pricing in Ethiopia: Do Urban 
Green Amenities Influence House Buyers' Decision? In proceedings of the 15th International Conference on Ethiopian Economy. July 20 - 22, Addis Ababa. pp.1-24.

Gitari, B. (2001). Valuation of up-market Residential properties in NairobiKenya. MA dissertation, Department of Land Development, University of Nairobi.

Hinkel, F. (2012). Essentials of Practical Real Estate Law (5th eds). United States: Delmar Learning.

Karoki, W.R. (2013). Determinants of Residential Real Estate Prices in Kenya. MBA dissertation, University of Nairobi.

Keller, E.J. \& Mukudi-Omwami, E. (2017). Rapid urban expansion and the challenge of pro-poor housing in Addis Ababa, Ethiopia, Africa Review, 9(2), pp.173-185. DOI: 10.1080/09744053.2017.1329809.

Kothari, C (2004). Research Methodology, Method, and Techniques (2nd eds). India: New Age International Ltd.

Larcombe, D.L., van Etten, E., Logan, A., Prescott, S.L. \& Horwitz, P. (2019). High-Rise Apartments and Urban Mental Health - Historical and Contemporary Views. Challenges, 10(34), pp.1-15. DOI: /10.3390/challe10020034.

Marczyk, G., DeMatteo, D. (2005). Essentials of Research Design and Methodology. United States: Wiley \& Sons.

Odumosu, J.O., Popoola, N.I., Ogungbenro, M.T. \& Falana, F.F. (2015). Empirical Model for Determination of Rent within M.I. Wushishi Housing Estate, Minna, Niger State. American Journal of Economics, 5(5), pp.449-457.

Oduwole, H. \& Eze, H. (2013). A Hedonic Pricing Model on Factors that Influence Residential Apartment Rent in Abuja Satellite Towns. Mathematical Theory and Modeling, 3(12), pp.65-74.

Pennings, P., Keman, H. \& Kleinnijenhuis, J. (2006). Doing Research in Political Science: An introduction to comparative methods and statistics.London: SAGE Publications.

Sayce, S. \& Smith, J. (2006). Real Estate Appraisal: From Value to Worth. Oxford: Blackwell Publishing Ltd.

Scarrett, D. (2008). Property Valuation: The Five Methods (2nd eds). New York: Routledge.

Shapiro, S.S. \& Wilk, M.B.(1965). An Analysis of Variance Test for Normality (Complete Samples). Biometrika, 52(3), pp.591-611.

Sirmans, S. \& Benjamin, B. (1991). Determinants of Market Rent. The Journal of Real Estate Research, 6(3), pp.457-379.

Tolon, U.W. (2008). Comparison of Urban Upgrading Projects on Development Cooperation in Ethiopia. Masters dissertation, Polytechnic University of Catalonia.

Wickramarachchi, N. (2007). Determinants of Rental Value for Residential Properties: A Landowner's Perspective for boarding homes. Built- 
environment: Sri Lanka, 12(1), pp.1-22.

Wong, S., Chau, K.W., Yau, Y. \& Cheung, A.K.C. (2011). Property Price Gradients: The Vertical Dimension. Journal of Housing and the Built Environment, 26(1), pp.33-45. DOI: 10.1007/s10901-010-9203-8.

Wyatt, P. (2013). Property Valuation. London: John Wiley \& Sons.

Wyatt, P. (2007). Property Valuation in an economic context. . London: John Wiley \& Sons. 